\title{
Characterization of Beet curly top virus Strains Circulating in Beet Leafhoppers (Hemiptera: Cicadellidae) in Northeastern Oregon
}

Silvia I. Rondon, Oregon State University, Hermiston Agricultural Research and Extension Center, Hermiston; Mary Sue Roster and Launa L. Hamlin, United States Department of Agriculture-Agricultural Research Service, Prosser, WA; and Kelsie J. Green, Alexander V. Karasev, and J. M. Crosslin, University of Idaho, Moscow

\begin{abstract}
Rondon, S. I., Roster, M. S., Hamlin, L. L., Green, K. J., Karasev, A. V., and Crosslin, J. M. 2016. Characterization of Beet curly top virus strains circulating in beet leafhoppers (Hemiptera: Cicadellidae) in northeastern Oregon. Plant Dis. 100:1586-1590.

The beet leafhopper, Circulifer tenellus, is an agriculturally important pest, particularly in the western United States. This insect transmits the Beet curly top virus (BCTV) to multiple crops, including bean, tomato, and pepper. In this study, we investigated the incidence of BCTV in individual leafhoppers collected at several sites in northeastern Oregon during the growing season in 2007, 2008, and 2009. Of the 800 insects tested, $151(18.9 \%)$ were found positive for the virus. Percentage of virus incidence varied from $0 \%$ at one location in 2009 to a high of $55.6 \%$ for a location sampled in 2008. The complete virus genomes from one virus-positive insect collected in each of the 3 years were determined. BLAST analysis of the BCTV whole-genome sequences from 2007, 2008, and 2009 insects showed 98, 94, and 96\% identities with the BCTV-

Worland sequence (AY134867), respectively. The BCTV_2008 sequence showed the greatest identity $(96 \%)$ with another BCTV genomic sequence (JN817383), and was found to be a recombinant between the BCTV-Worland type, representing the majority of the genome (approximately $2.2 \mathrm{~kb}$ ), and the BCTV-CFH type that provided an approximately 0.8 -kb fragment spanning replication-related genes $C 1$ and $C 2$. This area of the BCTV genome, between the $C 1$ and $C 2$ genes, was previously found to carry symptom determinants of the virus, and the data may suggest more severe effects of BCTV during the 2008 season. Results indicate that BCTV is common and widespread in C. tenellus in eastern Oregon and that there is substantial genetic diversity among the virus strains present in this important field and vegetable crop-growing region.
\end{abstract}

The beet leafhopper, Circulifer tenellus Baker (Homoptera: Cicadellidae), is a widespread and common insect endemic throughout the western and southwestern United States and parts of Europe, preferring arid and semiarid conditions (Cook 1967). The importance of this insect is largely due to its transmission of prokaryotic and viral pathogens. The most important plant virus that is transmitted by this insect is Beet curly top virus (BCTV; family Geminiviridae, genus Curtovirus). This virus has a very wide host range, including many important crop plants and numerous weed species (Thomas and Mink 1979). Economically important hosts include sugar beet (Beta vulgaris L.), tomato (Solanum lycopersicum L.), pepper (Capsicum spp.), bean (Phaseolus spp.), spinach (Spinacea oleracea L.), and a number of cucurbit species. Data on relative BCTV incidence in weeds and the importance of weeds in BCTV-caused disease epidemiology is limited (Creamer et al. 1996).

Several years ago, the taxonomy of BCTV was modified such that BCTV referred to the Cal/Logan strain, Beet mild curly top virus (BMCTV) to the Worland strain, and Beet severe curly top virus (BSCTV) to the CFH strain (Stenger 1994; Strausbaugh et al. 2008). However, a more recent evaluation of whole genomic Curtovirus sequences has proposed that BCTV, BMCTV, and BSCTV actually consist of only one species, BCTV (Varsani et al. 2014). Major strains of BCTV now include the Cal/Logan, Worland, and CFH strains. These three well-characterized strains of BCTV now serve to compare Curtovirus isolates to the other two proposed Curtovirus spp., Spinach severe curly top virus and Horseradish curly top virus (Varsani et al. 2014).

The southern Columbia River Basin of Washington and northeastern Oregon is an important agricultural area, and a number of field and vegetable crops are grown in this region due to the suitable soils, hot dry climate, and availability of irrigation water. These factors also

Corresponding author: S. I. Rondon; E-mail: silvia.rondon@oregonstate.edu Accepted for publication 30 March 2016.

http://dx.doi.org/10.1094/PDIS-10-15-1189-RE

(c) 2016 The American Phytopathological Society favor the types of vegetation that are suitable hosts of the beet leafhopper. A survey of leafhoppers conducted from 2003 to 2005 indicated that $C$. tenellus was common in weeds in the Columbia Basin from mid-April until at least mid-October and there were at least three generations a year (Munyaneza et al. 2008). Also, three morphological types of $C$. tenellus have been described; a summer, a winter, and a migratory morph (Severin 1931). Additional, recent work has focused on the occurrence of the prokaryotic pathogen, the beet leafhopper-transmitted virescence agent (BLTVA) phytoplasma, in populations of the beet leafhopper (Crosslin et al. 2012; Munyaneza et al. 2006, 2010), and population dynamics of BLTVA and the vector (Murphy et al. 2014).

The primary objective of the work described herein was to determine the incidence of BCTV in populations of the beet leafhopper in northeastern Oregon. A secondary objective was to identify the BCTV strains present within some of the virus-positive insects. Here, we have found BCTV to be an abundant virus present across the Columbia Basin, and identified at least two distinct genetic variants of BCTV carried by the leafhoppers in this area. This information will further our understanding of the importance of the beet leafhopper in diseases affecting crops in the Columbia Basin.

\section{Materials and Methods}

Sample collection. Beet leafhoppers were collected on yellow sticky traps weekly at 36 sites in Umatilla and Morrow Counties, OR, in April through November 2007, 2008, and 2009. Detailed site locations, including GPS coordinates, were described by Crosslin et al. (2012). A subset of 800 insects described by Crosslin et al. (2012), representing four (2007) or seven (2008 and 2009) collection sites, were selected for BCTV analysis. These sites tended to have higher numbers of leafhoppers over the duration of the collection period.

Nucleic acid extraction, polymerase chain reaction, and sequencing. Total nucleic acids were purified from individual leafhoppers using the cetyl-trimethyl ammonium bromide procedure (Crosslin et al. 2005; Zhang et al. 1998). Nucleic acid preparations were those previously used for detection of the BLTVA phytoplasma in the Oregon beet leafhoppers (Crosslin et al. 2012). Nucleic acid preparations $(2 \mu \mathrm{l})$ were initially tested for the presence of BCTV by polymerase 
chain reaction (PCR) using oligonucleotide primers designed using Primer Designer (Sci-Ed Software, Morrisville, NC) from the coat protein $(\mathrm{CP})$ region of the virus. Forward primer BCTV2 and reverse primer BCTV1 (Table 1) were used in 50- $\mu$ l PCR tests consisting of $10 \mu \mathrm{l}$ of GoTaq Green buffer (Promega Corp., Madison, WI), $0.5 \mu \mathrm{l}$ of $10 \mathrm{mM}$ dNTP solution, $1.0 \mu \mathrm{l}$ of each primer $(20 \mu \mathrm{M}), 35.3 \mu \mathrm{l}$ of sterile distilled water, and $0.2 \mu \mathrm{l}$ of GoTaq polymerase (Promega Corp.). Thermal cycling consisted of an initial incubation at $94^{\circ} \mathrm{C}$ for $2 \mathrm{~min}$; followed by 30 cycles of $94^{\circ} \mathrm{C}$ for $15 \mathrm{~s}, 58^{\circ} \mathrm{C}$ for $2 \mathrm{~min}$, and $72^{\circ} \mathrm{C}$ for $1 \mathrm{~min}$; followed by a final 10 -min incubation at $72^{\circ} \mathrm{C}$. Reactions were held at $4^{\circ} \mathrm{C}$ until tested by electrophoresis $(10 \mu \mathrm{l})$ on $1.5 \%$ agarose gels stained with ethidium bromide. Gels were observed under ultraviolet light (Gel Doc; Bio-Rad, Hercules, $\mathrm{CA}$ ) and presence of the predicted 500-bp amplicon indicated that a sample was positive for BCTV.

BLAST sequence analysis (Altschul et al. 1990) of the BCTV1 and BCTV2 primer sequences indicated $100 \%$ identity with viruses BCTV Cal/Logan strain, GenBank M24597; Worland strain, GenBank AY134867; and CFH strain, GenBank U02311, (Stenger 1994; Stenger and Ostrow 1996; Strausbaugh et al. 2008) and, therefore, should detect any of these curtoviruses present in the leafhopper samples.

Subsequent PCR tests utilized primers 2097F/2387R, 2213F/2609R, and $2315 \mathrm{~F} / 2740 \mathrm{R}$ as described by Strausbaugh et al. (2008) in order to differentiate "BCTV", "BMCTV", and "BSCTV" strains, respectively. Finally, primers OutF, OutR, 328F, 455F, and 945R (Table 1) were used in conjunction with the primers described above to produce overlapping amplicons representing entire virus genomes from three insects that tested virus-positive in the initial test; one each from the 3 years of the study, selected randomly. The three insects chosen were collected at different sites: 35, 14, and 19 (Crosslin et al. 2012) for the 2007, 2008, and 2009 samples, respectively. The additional PCR tests generated five overlapping amplicons representing the entire BCTV genome (reference sequence GenBank AY134867). PCR conditions were as described above for primer pair BCTV1/BCTV2. These last PCR tests included the BCTV1/BCTV2 primer pair described above, pair 328F/945R, pair 455F/945R, pair OutF/2609R, and pair OutR/2213F (Table 1). Amplicons for the BCTV1/BCTV2, 328F/945R, 455F/945R, OutF/2609R, and OutR/2213F pairs were approximately 500, 618, 491, 1,700 , and 1,100 bp in size, respectively.

Amplified products produced with the various PCR primer pairs were purified (Wizard SV PCR Clean-Up Kit; Promega Corp.), quantitated with a NanoDrop instrument, and directly sequenced with the primers used for amplification (ELIM Biopharmaceuticals, Hayward, CA).

Sequence analysis. For the multiple sequence alignment, CLUSTALW (Thompson et al. 1994) implemented in the program MEGA, version 7 (Tamura et al. 2007), was used with the default parameters. Sequence identity was checked using the BLAST program provided by the National Center for Biotechnology Information. Alignments were conducted based on the whole genome of representative isolates of BCTV strains. The aligned sequences were checked for recombination using the RDP4 package of programs (Martin and Rybicki

Table 1. Polymerase chain reaction primers used for testing of beet leafhoppers and determination of full Beet curly top virus (BCTV) genomic sequences

\begin{tabular}{llr}
\hline $\begin{array}{l}\text { Primer } \\
\text { name }\end{array}$ & \multicolumn{1}{c}{ Sequence $\left(\mathbf{5}^{\prime} \mathbf{-} \mathbf{3}^{\prime}\right)$} & Reference \\
\hline BCTV1 & CTCCTTCACGTCTTCATACT & This article \\
BCTV2 & GTGCTGGTGGTATAGGATCT & This article \\
$328 \mathrm{~F}$ & ATGGGACCTTTCAGAGTGGA & This article \\
$455 \mathrm{~F}$ & CCCTAGAAGAAGGCGAGGTC & This article \\
$945 \mathrm{R}$ & GGGAACACTGACCCAACATC & This article \\
OutF & GTTGAATAATTAYGTBCAGGG & This article \\
OutR & CTCGCCTTCTTCTAGGGTCAG & This article \\
2213F & GGCATCCACCCCGAAATAAGAATC & $\begin{array}{r}\text { Strausbaugh } \\
\text { et al. 2008 }\end{array}$ \\
$2609 \mathrm{R}$ & CGACATCACTCATCCTTCCTCAAGC & $\begin{array}{r}\text { Strausbaugh } \\
\text { et al. 2008 }\end{array}$ \\
\hline
\end{tabular}

2000), GENECONV (Sawyer 1999), BOOTSCAN (Salminen et al. 1995), MAXCHI (Maynard-Smith 1992), CHIMAERA (Posada and Crandall 2001), 3Seq (Boni et al. 2007), and SiScan (Gibbs et al. 2000) methods in RDP4 Beta4.61 software (Martin et al. 2005). The analyses in RDP4 Beta4.61 package were done using default settings and a Bonferroni-corrected $P$ value cut-off of 0.05 . Only recombination points detected by more than four methods in the RDP4 Beta4.61 program were taken into consideration. Phylogeny inference was conducted based on the whole genomes using the maximum-likelihood implemented in MEGA, version 7 (Tamura et al. 2007), with 100 bootstrap replicates.

\section{Results}

BCTV incidence and strain composition. PCR tests with primers BCTV1 and BCTV2 detected BCTV in zero to more than half of the individual beet leafhoppers collected at the various locations in the 3 years of the study. A portion of one agarose gel with PCR results on some of the insects from the 2009 collection is shown in Figure 1. Results of all PCR testing with primers BCTV1 and BCTV2 are shown in Table 2. Samples from only one site-year combination showed no BCTV in the tested insects (site 10 in 2009; $n=25$ ). The average BCTV incidence across all sites and years was $18.9 \%$. Site 35 yielded the highest percentage of positive insects in each of the 3 years (Table 2).

The highest incidence of virus-positive leafhoppers generally occurred in late June through August in each of the 3 years (data not shown). A subset of positive leafhopper samples was tested with primer pairs $2097 \mathrm{~F}$ and $2387 \mathrm{R}, 2213 \mathrm{~F}$ and $2609 \mathrm{R}$, and $2315 \mathrm{~F}$ and $2740 \mathrm{R}$. Samples amplified only with primer pair $2213 \mathrm{~F} / 2609 \mathrm{R}$. These results suggested that the insects carried "BMCTV" and not "BCTV" or "BSCTV" (Strausbaugh et al. 2008) (data not shown). However, it needs to be pointed out that all differentiating primers described by Strausbaugh et al. (2008) target the V1/CP region, similarly to our own BCTV1/BCTV2 primer pair (Table 1); hence, the matching identification of the Worland-like sequences between our primers and primers described by Strausbaugh et al. (2008) is fully expected.

Sequencing and whole-genome sequence analysis. The three whole-genome sequences for the viruses detected in the 2007, 2008, and 2009 insects were deposited into GenBank as accessions KU892789 (BCTV_2007), KU892790 (BCTV_2008), and KU892791 (BCTV_2009). BLAST analysis of the complete virus genomes from the 2007, 2008, and 2009 insects showed 98, 94, and 96\% identities with the BCTV "Worland" sequence (AY134867), respectively. The 2008 sequence, however, showed the greatest identities (96 to 97\%) with other BCTV genomic sequences (JN817383 and KT276899 to KT276901). On the other hand, the 2007, 2008, and 2009 sequences showed 89, 94, and $88 \%$ identity, respectively, with the BCTV CFH strain. All three sequences would be relegated to the previous "mild" or "Worland" strain clade according to our PCR-based typing; however, the BCTV_2008 sequence differed from the other two.

The recombination analysis performed with the RDP4 programs identified isolate BCTV_2008 as a recombinant sequence homologous

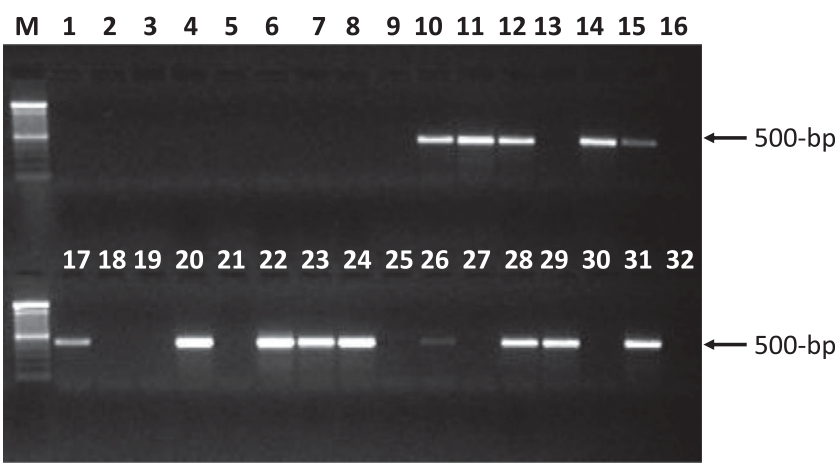

Fig. 1. Portion of agarose gel showing polymerase chain reaction products obtained with oligonucleotide primers Beet curly top virus (BCTV)1 and BCTV2 on 32 insect samples from 2009. At left is a 100-bp DNA ladder. Presence of the predicted 500bp amplicon indicates insect was positive for BCTV. 
to the Worland genome for the approximately $2.2 \mathrm{~kb}$ of its length but carrying a 770-nucleotide (nt) fragment homologous to the CFH sequence (Table 3; Figs. 2 and 3). This 770-nt segment homologous to the $\mathrm{CFH}$ sequence partially spanned coding frames for the $\mathrm{Cl}$ and $C 2$ genes (Fig. 2). The closely related BCTV sequence JN817383 was also found to be recombinant, with a similar recombinant structure: it carried a $\mathrm{CFH}$-homologous segment within an otherwise Worland-homologous genome (Fig. 3). In the case of JN817383, however, the position of the CFH-like sequence was slightly shifted downstream along the complementary strand, and this CFH homologous segment was shorter. Three other BCTV sequences in the GenBank database were identified as displaying similar recombinant structures, with Worland and CFH being parental sequences and having recombination breakpoints in slightly different positions (Table 3).

\section{Discussion}

Previous research demonstrated the widespread and season-long occurrence of beet leafhoppers in northeastern Oregon (Crosslin et al. 2012; Murphy et al. 2014) and south-central Washington (Munyaneza et al. 2008) and documented the common occurrence of the BLTVA phytoplasma in leafhoppers collected in these areas. The work described herein expands upon the previous work and shows that this insect is also a common carrier of BCTV in this region. This virus infects many important vegetable crops grown in the lower Columbia Basin region of Washington and Oregon, including sugar beet, tomato, pepper, bean, spinach, and cucurbits. Many common weeds in this part of the Pacific Northwest are also common hosts of BCTV and the beet leafhopper, including Russian thistle (Salsola kali L.) and kochia (Kochia scoparia L.), which are very widespread and remain green throughout the cropping season and into the late fall. These two weeds, and other species as well, also provide a source of the virus for acquisition by the leafhopper vector, as has been demonstrated in California and other important agricultural production areas (Chen et al. 2010; Creamer et al. 1996; Hudson et al. 2010; Wisler and Duffus 2000).

Although it has been known for decades that $C$. tenellus transmits BCTV (Bennett 1971), relatively little work has been done related to the incidence of virus in individual insects. Severin (1925) reported
$17 \%$ transmission from individual beet leafhoppers and subsequently reported (Severin 1931) that 13 to $40 \%$ of individual beet leafhoppers transmitted the beet curly top agent to sugar beet plants. This percent transmission is in general agreement with the virus incidence in beet leafhoppers reported herein. Chen et al. (2010) reported the detection of BCTV in leafhopper samples by PCR; however, these researchers used composites of up to 15 insects in their tests and, therefore, the virus status of individual insects could not be determined.

Initial sequencing of the BCTV1/BCTV2 amplicon suggested the presence of "BMCTV" (Worland strain) in the insects (data not shown). When the additional amplicons were sequenced and the entire virus genome was determined for the three isolates of BCTV collected, this conclusion was confirmed for two of them, BCTV_2007 and BCTV_2009 (Fig. 2). The third isolate, BCTV_2008, was found to be a recombinant between the Worland and CFH strains of BCTV (Figs. 2 and 3), with the sequence homologous to the CFH representing about $25 \%$ of the virus genome and spanning the $3^{\prime}$-terminal segment of the $C 1$ gene and the $5^{\prime}$-terminal segment of the $C 2$ gene (Fig. 2). This isolate was also identified as a Worland-like sequence using

Table 3. Positions of the recombinant breakpoints in the Beet curly top virus (BCTV) isolates studied in this work

\begin{tabular}{lccl}
\hline Isolate name & Strain & Breakpoints $^{\mathbf{a}}$ & GenBank accession \\
\hline BCTV_2007 & Worland & NR & KU892789 (this work) \\
BCTV_2008 & $?$ & $1.735 ; 2.505$ & KU892790 (this work) \\
BCTV_2009 & Worland & NR & KU892791 (this work) \\
pCO_95_6_31 & $?$ & $1.715 ; 2.385$ & JN817383 \\
CTS14_01 & $?$ & $1.720 ; 2.500$ & KT276899 \\
CTS14_14 & $?$ & $1.720 ; 2.500$ & KT276900 \\
CTS14_24 & $?$ & $1.720 ; 2.455$ & KT276901 \\
BMCTV_Worland & Worland & NR & U56975 \\
BMCTV_Worland44 & Worland & NR & AY134867 \\
CFH_Beta & Severe CFH & NR & U02311 \\
CFH_Beta & Severe CFH & NR & X97203 \\
\hline
\end{tabular}

${ }^{\text {a }}$ Sequence alignment length $=3,133$; in all events, $P$ value $<0.0001 ; \mathrm{NR}=$ nonrecombinant.

Table 2. Incidence of Beet curly top virus (BCTV) in beet leafhoppers collected in northeastern Oregon in 2007, 2008, and 2009ª

\begin{tabular}{|c|c|c|c|c|}
\hline Year, site ${ }^{b}$ & GPS coordinates & BCTV positive (n) & Tested $(n)$ & Positive (\%) \\
\hline \multicolumn{5}{|l|}{2007} \\
\hline 4 & N 45.51.508 W 119.06.546 & 10 & 75 & 13.3 \\
\hline 10 & $\mathrm{~N}$ 45.43.561 W 119.12.827 & 5 & 80 & 6.3 \\
\hline 31 & N 45.45.765 W 119.27.364 & 9 & 50 & 18.0 \\
\hline 35 & N 45.49.028 W 119.17.411 & 11 & 45 & 24.4 \\
\hline Total & $\ldots$ & 35 & 250 & 14.0 \\
\hline \multicolumn{5}{|l|}{2008} \\
\hline 4 & N 45.51.508 W 119.06.546 & 9 & 64 & 14.1 \\
\hline 10 & $\mathrm{~N}$ 45.43.561 W 119.12.827 & 4 & 20 & 20.0 \\
\hline 31 & N 45.45.765 W 119.27.364 & 5 & 57 & 8.8 \\
\hline 35 & N 45.49.028 W 119.17.411 & 35 & 63 & 55.6 \\
\hline 0 & N 45.45.461 W 119.48.790 & 3 & 10 & 30.0 \\
\hline 14 & $\mathrm{~N} 45.52 .773 \mathrm{~W} 119.22 .505$ & 7 & 20 & 35.0 \\
\hline 19 & $\mathrm{~N} 45.52 .305 \mathrm{~W} 119.32 .903$ & 4 & 35 & 11.4 \\
\hline Total & $\ldots$ & 67 & 269 & 24.9 \\
\hline \multicolumn{5}{|l|}{2009} \\
\hline 4 & N 45.51.508 W 119.06.546 & 8 & 59 & 13.6 \\
\hline 10 & $\mathrm{~N}$ 45.43.561 W 119.12.827 & 0 & 25 & 0.0 \\
\hline 31 & $\mathrm{~N} 45.45 .765 \mathrm{~W} 119.27 .364$ & 1 & 20 & 5.0 \\
\hline 35 & N 45.49.028 W 119.17.411 & 17 & 48 & 35.4 \\
\hline 0 & N 45.45.461 W 119.48.790 & 9 & 35 & 25.7 \\
\hline 14 & $\mathrm{~N} 45.52 .773 \mathrm{~W} 119.22 .505$ & 2 & 34 & 5.9 \\
\hline 19 & $\mathrm{~N} 45.52 .305 \mathrm{~W} 119.32 .903$ & 12 & 60 & 20.0 \\
\hline Total & $\ldots$ & 49 & 281 & 17.4 \\
\hline 3-Year total & $\ldots$ & 151 & 800 & 18.9 \\
\hline
\end{tabular}

\footnotetext{
${ }^{\text {a }}$ Insects were tested by polymerase chain reaction with primer pair BCTV1 and BCTV2; $n=$ number of leafhoppers.
}

${ }^{\mathrm{b}}$ Collection year and site number. Site locations can be found in Crosslin et al. (2012). 
our BCTV1/BCTV2 primer pair, because it targeted the V1/CP area of the BCTV genome, outside of the area that underwent recombination.

This is the first study of BCTV strains circulating in beet leafhoppers in a specific geographic area over a period of 3 years, 2007 to 2009. Interestingly, the data collected suggest dynamic changes in the strain composition of BCTV found in its leafhopper vectors. Presence of the Worland/CFH recombinant similar to the virus strain found in Colorado in the mid-1990s is especially intriguing. The position of the recombinant segment coming from the $\mathrm{CFH}$ parent that spans the $C 1$ and $C 2$ genes suggests that this recombinant may have biological differences from both parents. It was demonstrated previously that the $\mathrm{C} 2$ protein affects BCTV symptom expression (Rojas et al. 2005), while the $\mathrm{C} 1$ protein is a rep-protein involved in BCTV replication. The network of yellow traps used to collect leafhoppers in this work could not distinguish between leafhoppers visiting various crops grown in the Columbia Basin of Oregon and, consequently, we could not assign these Worland-like sequences to any specific crop.

Although our tests described herein only detected "BMCTV" (i.e., viruses related to the Worland strain) or the BCTV_2008 recombinant, in the leafhoppers that were tested, the "BCTV" and "BSCTV" strains were found in sugar beet in Oregon in 2006 and 2007 (Strausbaugh et al. 2008). Our results would suggest, however, that viruses closely related to the Worland strain may predominate in beet leafhoppers in the Hermiston-Umatilla region of northeastern Oregon.
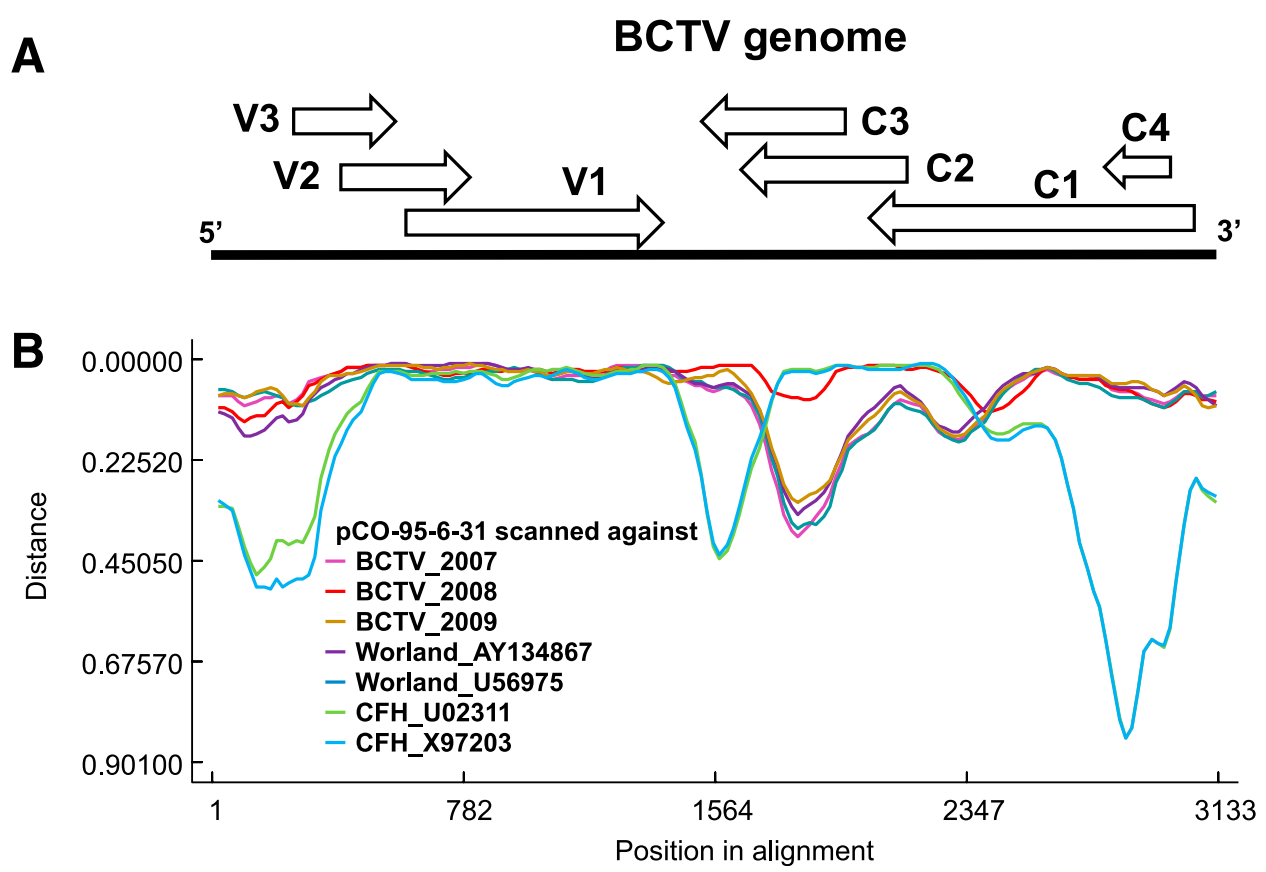

Fig. 2. A, Schematic diagram showing Beet curly top virus (BCTV) genome with positions of genes coded in the virion-sense (V) and the complementary (C) directions. B, Manual distance plot based on the aligned full-length nucleotide sequences of BCTV isolates BCTV_2007, BCTV_2009, pCO-95-6-31 (JN817383), Worland (AY134867), Worland (U56975), CFH (U02311), and CFH (X97203); BCTV_2008 (GenBank accession KU892790) was used as the reference strain. The X-axis represents nucleotide position in the alignment and the $y$-axis represents relative distance from the reference sequence, which is calculated using the Kimura model (Kimura 1980).
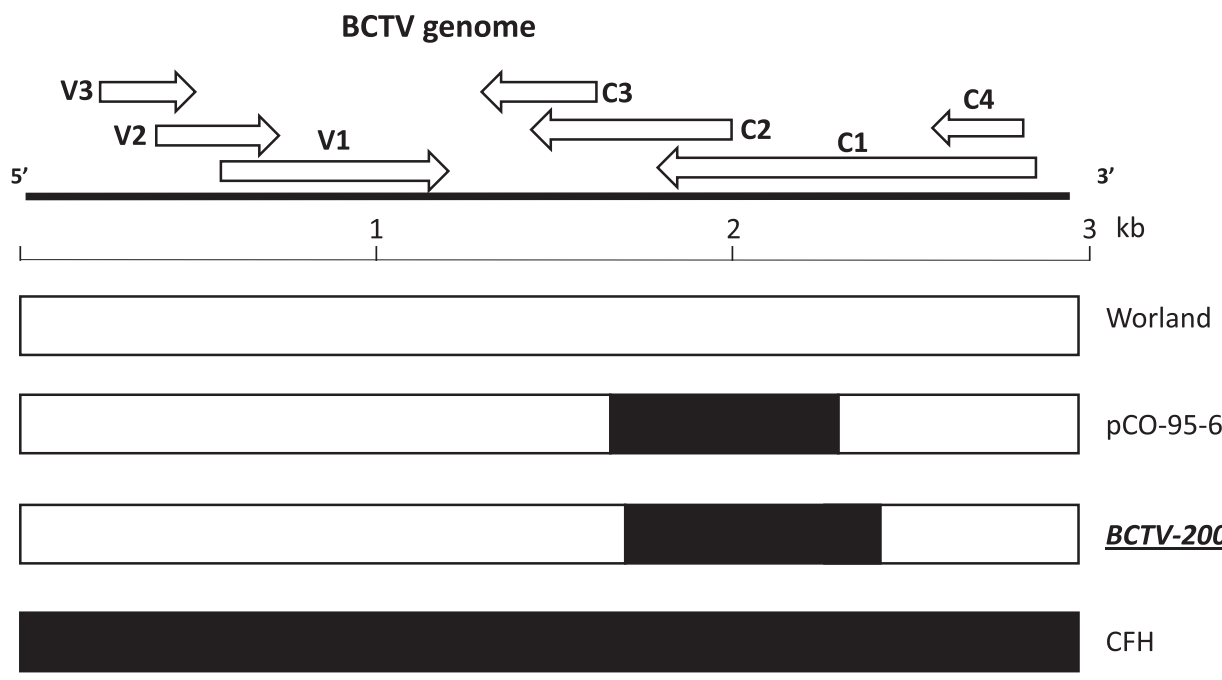

pCO-95-6-31

$\underline{B C T V-2008}$

$\mathrm{CFH}$

Fig. 3. Schematic diagram showing putative Beet curly top virus (BCTV) recombination structures for BCTV_2008 and pCO-95-6-31 relative to parental sequences of Worland and $\mathrm{CFH}$ strains. The diagram reflects distance plot data presented in Figure 2. Similar shading of the rectangles indicates homologous sequences present in BCTV strains Worland and $\mathrm{CFH}$. 


\section{Acknowledgments}

This work was funded, in part, through grants provided by the Oregon Potato Commission, Idaho Bean Commission, Snake River Sugar Beet Research Alliance, and the Idaho Agricultural Experiment Station.

\section{Literature Cited}

Altschul, S., Gish, W., Miller, W., Myers, E., and Lipman, D. 1990. Basic local alignment search tool. J. Mol. Biol. 215:403-410.

Bennett, C. W. 1971. The Curly Top Disease of Sugarbeet and Other Plants. American Phytopathological Society, St. Paul, MN.

Boni, M. F., Posada, D., and Feldman, M. W. 2007. An exact nonparametric method for inferring mosaic structure in sequence triplets. Genetics 176:1035-1047.

Chen, L.-F., Brannigan, K., Clark, R., and Gilbertson, R. L. 2010. Characterization of curtoviruses associated with curly top disease of tomato in California and monitoring for these viruses in beet leafhoppers. Plant Dis. 94:99-108.

Cook, W. C. 1967. Life history, host plants, and migrations of the beet leafhopper in the western United States. U. S. Dep. Agric. Tech. Bull. 1365.

Creamer, R., Luque-Williams, M., and Howo, M. 1996. Epidemiology and incidence of beet curly top geminivirus in naturally infected weed hosts. Plant Dis. 80:533-535.

Crosslin, J. M., Munyaneza, J. E., Jensen, A., and Hamm, P. B. 2005. Association of beet leafhopper (Hemiptera: Cicadellidae) with a clover proliferation group phytoplasma in Columbia Basin of Washington and Oregon. J. Econ. Entomol. 98:279-283.

Crosslin, J. M., Rondon, S. I., and Hamm, P. B. 2012. Population dynamics of the beet leafhopper in northeastern Oregon and incidence of the beet leafhoppertransmitted virescence agent phytoplasma. Am. J. Potato Res. 89:82-88.

Gibbs, M. J., Armstrong, J. S., and Gibbs, A. J. 2000. Sister-scanning: A Monte Carlo procedure for assessing signals in recombinant sequences. Bioinformatics 16:573-582.

Hudson, A., Richman, D. B., Escobar, I., and Creamer, R. 2010. Comparison of the feeding behavior and genetics of beet leafhopper, Circulifer tenellus, populations from California and New Mexico. Southwest. Entomol. 35:241-250.

Kimura, M. 1980. A simple method for estimating evolutionary rates of base substitutions through comparative studies of nucleotide sequences. J. Mol. Evol. 16:111-120.

Martin, D., and Rybicki, E. 2000. RDP: Detection of recombination amongst aligned sequences. Bioinformatics 16:562-563.

Martin, D., Williamson, C., and Posada, D. 2005. RDP2: Recombination detection and analysis from sequence alignment. Bioinformatics 21:260-262.

Maynard-Smith, J. 1992. Analyzing the mosaic structure of genes. J. Mol. Evol. 34:126-129.

Munyaneza, J. E., Crosslin, J. M., and Upton, J. E. 2006. Beet leafhopper (Hemiptera: Cicadellidae) transmits the Columbia Basin potato purple top phytoplasma to potatoes, beets, and weeds. J. Econ. Entomol. 99:268-272.

Munyaneza, J. E., Crosslin, J. M., Upton, J. E., and Buchman, J. L. 2010. Incidence of the beet leafhopper-transmitted virescence agent phytoplasma in local populations of the beet leafhopper, Circulifer tenellus, in Washington State. J. Insect Sci. 10:Article 18. doi:10.1673/031.010.1801
Munyaneza, J. E., Jensen, A. S., Hamm, P. B., and Upton, J. E. 2008. Seasonal occurrence and abundance of beet leafhopper in the potato growing region of Washington and Oregon Columbia Basin and Yakima Valley. Am. J. Potato Res. 85:77-84.

Murphy, A. F., Rondon, S. I., Marchosky, R., Buckman, J., and Munyaneza, J. E. 2014. Evaluation of beet leafhopper transmitted virescence agent damage in the Columbia Basin. Am. J. Pot. Res. 91:101-108.

Posada, D., and Crandall, K. A. 2001. Evaluation of methods for detecting recombination from DNA sequences: Computer simulations. Proc. Natl. Acad. Sci. USA 98:13757-13762.

Rojas, M. R., Hagen, C., Lucas, W. J., and Gilbertson, R. L. 2005. Exploiting chinks in the plant's armor: Evolution and emergence of geminiviruses. Annu. Rev. Phytopathol. 43:361-394.

Salminen, M. O., Carr, J. K., Burke, D. S., and McCutchan, F. E. 1995. Identification of breakpoints in intergenotypic recombinants of HIV type 1 by bootscanning. AIDS Res. Hum. Retroviruses 11:1423-1425.

Sawyer, S. A. 1999. GENECONV: A Computer Package for the Statistical Detection of Gene Conversion. Online publication. Distributed by the author, Department of Mathematics, Washington University, St. Louis. http://www. math.wustl.edu/ sawyer

Severin, H. H. P. 1925. Percentage of curly leaf infection in beet leafhopper (Eutettix tenella Baker) and winter host plants under field conditions. J. Econ. Entomol. 18:733-737.

Severin, H. H. P. 1931. Modes of curly-top transmission by the beet leafhopper, Eutettix tenellus (Baker). Hilgardia 6:253-276.

Stenger, D. C. 1994. Complete nucleotide sequence of the hypervirulent CFH strain of beet curly top virus. Mol. Plant-Microbe Interact. 7:154-157.

Stenger, D. C., and Ostrow, K. M. 1996. Genetic complexity of a beet curly top virus population used to assess sugar beet cultivar response to infection. Phytopathology 86:929-933.

Strausbaugh, C. A., Wintermantel, W. M., Gillen, A. M., and Eujayl, I. A. 2008 Curly top survey in the western United States. Phytopathology 98:1212-1217.

Tamura, K., Dudley, J., Nei, M., and Kumar, S. 2007. MEGA: Molecular Evolutionary Genetics Analysis software version 4. Mol. Biol. Evol. 24:1596-1599.

Thomas, P. E., and Mink, G. I. 1979. Beet curly top virus. CMI-AAB Descriptions of Plant Viruses, No. 210. Association of Applied Biologists, Wellesbourne, Warwick, U.K.

Thompson, J. D., Higgins, D. G., and Gibson, T. J. 1994. CLUSTAL W: Improving the sensitivity of progressive multiple sequence alignment through sequence weighting, position-specific gap penalties and weight matrix choice. Nucleic Acids Res. 22:4673-4680.

Varsani, A., Martin, D. P., Navas-Castillo, J., Moriones, E., Hernandez-Zepeda, C., Idris, A., Zerbini, F. M., and Brown, J. K. 2014. Revisiting the classification of curtoviruses based on genome-wide pairwise identity. Arch. Virol. 159:1873-1882.

Wisler, G. C., and Duffus, J. E. 2000. A century of plant virus management in the Salinas Valley of California, 'East of Eden'. Virus Res. 71:161-169.

Zhang, Y.-P., Uyemoto, J. K., and Kirkpatrick, B. C. 1998. A small-scale procedure for extracting nucleic acids from woody plants infected with various phytopathogens for PCR assay. J. Virol. Methods 71:45-50. 